УДК 373.2.091:004.773.6-049.5

(C) Штефан М. В., 2021 p.

http://orcid.org/0000-0002-0304-1567

DOI: $10.34142 / 23128046.2021 .51 .16$

M. В. Штефан

\title{
СТВОРЕННЯ БЕЗПЕЧНОГО РОЗВИВАЛЬНОГО СЕРЕДОВИЩА ОНЛАЙН ЗАНЯТЬ ХУДОЖНЬО-ПРОДУКТИВНОЮ ДІЯЛЬНІСТЮ СТАРШИХ ДОШКІЛЬНИКІВ
}

У статті представленні результати досліджень щзодо стану $i$ перспективи використання інформаційно-комунікаційних технологї для організаиії художньо-продуктивної діяльності дітей стариого дошкільного віку шляхом анкетування педагогічних працівників $і$ батьків. На основі результатів анкетування автором було розроблено цикл онлайн занять 3 художньо-продуктивної діяльності для дітей старшого дошкільного віку, визначено фактори та перспективні напрями щзодо створення безпечного розвивального середовища онлайн занять художньо-продуктивною діяльністю дітей старшого дошкільного віку.

У ході дослідження було розроблено і здійснено анкетування педагогічних прачівників закладів дошкільної освіти м. Харкова. Результати його засвідчили про зацікавленість педагогічних працуівників ідеями дистанціийної освіти дітей старшого дошкільного віку. 3'ясовано, шзо ідея безпечного розвивального середовища онлайн занять художньо-продуктивною діяльністю дітей старшого дошкільного віку полягає в тому, щуоб інтегрувати знання в цілісне явище, максимально наближене до реального буття дитини (в онлайн-заняттях варто враховувати специифіку перебування дітей в сім $і$, логіку карантинних заходів тощуо). Онлайн заняття допомагають дитині створювати продукт, формувати культуру інформаційну, цицфрову, загальну.

Ситуащійний характер завдань дає право на множинність припустимих рімень. Особливо значимим для дитини старшого дошкільного віку $\epsilon$ можливість презентувати $i$ зафіксувати своє досягнення. Зміст $i$ рівень самостійної діяльності залежать від досвіду дітей у володінні конкретним видом діяльності, їхньої життєвої компетентності, наявності розвивального предметно-ігрового, природного, соціального середовища, врахування власного продуктивного простору кожної дитини. Це передбачає грамотне, дозоване керівництво з боку дорослого.

Перспективним напрямом подальшого розроблення заявленої проблеми вбачаємо налагодження співпрац̧і педагогів $i$ батьків дітей щзодо організації доцільних занять художньо-продуктивною діяльністю дітей онлайн, офлайн, за розробленими інструкціями чи простим алгоритмом дій. Наскрізним має стати завдання конкретики в осмисленні і розумінні позицій цүифрової, комп 'ютерної безпеки для фізичного і психічного здоров'я дитини старшого дошкільного віку. 
Ключові слова: художня діяльність, продуктивна діяльність, онлайн, дошкільники, заняття.

Shtefan M. V. Creating a safe developmental environment at online classes of art and productive activities of senior preschool children. The article presents the results of research on the status and prospects of using information and communication technologies for the organization of artistic and productive activities of senior preschool children by questioning teachers and parents. Based on the results of the questionnaire, the author has developed a series of online classes on artistic and productive activities for senior preschool children, factors and promising areas for creating a safe developmental environment for online classes of artistic and productive activities for senior preschool children have been identified. In the course of the research a questionnaire of pedagogical workers of preschool education institutions of Kharkiv was developed and carried out. Its results testified to the interest of pedagogical workers in the ideas of distance education of senior preschool children. It has been established that the idea of a safe developmental environment for online art and productive activities of senior preschool children is to integrate knowledge into a holistic phenomenon as close as possible to the real life of the child (online classes should take into account the specifics of family stay, logic of quarantine measures, etc.). Online classes help the child to create a product, to form informational, digital, general culture. The situational nature of the tasks gives the right to a plurality of acceptable solutions. Especially important thing for a child of senior preschool age is the opportunity to present and record their achievements. The content and level of independent activity depend on the experience of children a particular activity, their life competence, the availability of developmental subject-game, natural, social environment, taking into account a productive space of each child. This involves competent, dosed guidance from an adult.

A promising direction for further development of the stated problem is seen in the establishment of cooperation between teachers and parents in the organization of appropriate classes of artistic and productive activities of children online, offline according to the developed instructions or a simple algorithm of actions. The task of specificity in understanding the positions of digital, computer security for the physical and mental health of a child of senior preschool age should be cross-cutting.

Keywords: artistic activity, productive activity, online, preschool children.

Вступ. Актуальність організації різних видів діяльності дітей старшого дошкільного віку в умовах дистанційної освіти в Україні важко переоцінити. Перші спроби проведення дистанційних занять із дітьми старшого дошкільного віку засвідчили чимало проблемних питань. Зокрема, виявлено, що не можна формально перенести програми розвитку дітей старшого дошкільного віку (цільовий і змістовий компоненти) з реальної освітньої практики у сферу онлайнвзаємодії батьків дітей, дітей і вихователів закладів дошкільної освіти. У листі МОН № 1/9-219 від 23.04.2020 «Щодо організації роботи закладів дошкільної 
освіти під час карантину» керівники ЗДО отримали рекомендації щодо ефективної організації освітнього процесу (Lyst Ministerstva osvity i nauky Ukrainy «Shchodo orhanizatsii roboty zakladiv doshkilnoi osvity pid chas karantynu», 2020). Також у рекомендаціях МОН запропоновано методичні розробки i навчальний контент для проведення онлайн занять із старшими дошкільниками в режимі реального часу (15 dniv VchymosiaVdoma, n.d.).

Спроби організації елементів дистанційної освіти 3 дітьми дошкільного віку побіжно висвітлено в роботах І. Дичківської (Dychkivska, 2012), Н. Любченко, О. Прокопенко, А. Виноградової (Liubchenko, 2012), С. Дяченко (Diachenko, 2009). Матеріали, представлені у цих працях, стосувалися змішаної, загальної, професійної освіти. Дослідженню особливостей художньопродуктивної діяльності дітей цього віку в Україні присвячені роботи В. Ворожбіт-Горбатюк (Vorozhbit-Horbatiuk \& Shtefan, 2021; VorozhbitHorbatiuk, Popovych \& Herber, 2018), Т. Житнік (Zhytnik, 2015), А. Івершинь (Ivershyn, 2001), О. Попович, С. Гербер (Popovych \& Herber, 2018).

Мета та завдання. Проведене дослідження переслідувало за мету: 3'ясувати стан і перспективи використання ІКТ для організації художньопродуктивної діяльності дітей старшого дошкільного віку в практиці створення безпечного розвивального середовища онлайн. Очікуваним результатом дослідної роботи, яку ми проводили, має стати інноваційний продукт - модель оновленого безпечного розвивального середовища в закладах дошкільної освіти на основі поєднання традиційних форм освітньої взаємодії і інформаційнокомунікативних технологій, розроблення програми занять художньопродуктивною діяльністю для старших дошкільників; забезпечення психологічного комфорту освітньої взаємодії для усіх учасників.

Методи дослідження. Методами дослідження обрано: теоретичний аналіз науково-педагогічних джерел із обраної проблеми та продуктів діяльності дітей; синтез, узагальнення досвіду для відбору змісту авторських відео-занять; опитування батьків і вихователів закладів дошкільної освіти (розроблення оригінального опитувальника і проведення реального анкетування за допомогою гугл-форми); бесіди 3 ними 3 метою виявлення думок щодо результатів анкетування; математичної статистики - для перевірки вірогідності результатів анкетування.

Результати. Дослідження передбачало проведення анкетування педагогічних працівників у закладах дошкільної освіти м. Харкова. Опитуванням було охоплено 374 бажаючих. Результати відповіді на питання «Який Ваш стаж роботи в закладі дошкільної освіти?» засвідчили про відносну рівномірність кадрового складу закладів дошкільної освіти у місті. Серед зацікавлених проблемою дистанційної освітньої взаємодії у закладах дошкільної 
освіти м. Харкова, 17,1\% респондентів мали стаж до 3 років, 24,9\% - 10-20 років, $34 \%$ - понад 30 років педагогічного стажу.

Оскільки ми переслідували мету виявити можливості вивчення цифрової компетентності педагогічних працівників, які забезпечують освітній процес для старших дошкільників у закладах дошкільної освіти, було визначено питання стосовно наявного фактичного досвіду проведення занять, спрямованих на формування компетентності «комп'ютерна грамотність», яка виокремлена у Базовому компоненті дошкільної освіти (нова редакція) у варіативній складовій в окрему освітню лінію «Комп'ютерна грамотність», що передбачає формування інформативної компетенції дошкільника (Bazovyi komponent doshkilnoi osvity, n.d.).

У ході опитування з'ясовано, що варіативна складова не була реалізована повною мірою в освітній практиці. Труднощі, які стали виразним показником низького рівня підготовки і реалізації ідеї дитячого садка онлайн, зумовлені хибним стереотипним уявленням про шкоду використання сучасних цифрових гаджетів для загального розвитку дитини дошкільного віку. Цим пояснюється очевидна відстороненість педагогічних працівників закладів дошкільної освіти від проблеми формування цифрової грамотності власне своєї і вихованців.

У першу чергу освітяни і батьки дітей дошкільного віку керувалися доцільним обмеженням доступу через ймовірну шкоду здоров'ю і загальному розвитку дитини. Як наслідок, поза системою виховних впливів опинилися питання цифрової грамотності і інтернет-безпеки дитини старшого дошкільного віку, сприйняття цифрових гаджетів лише як ресурсу розваг і відпочинку, а не розвивального, навчального чи середовища активної пізнавальної, художньопродуктивної діяльності.

Наголосимо увагу на тому, що подібні результати стали наслідком хибних стереотипних уявлень. Діти, народжені в епоху прогресування цифрових, інформаційно-комунікаційних технологій не усвідомлюють самої можливості існування світу і себе у світі без гаджетів. Відмова чи обмеження не дасть позитивної динаміки загального розвитку і бажаної безпеки. Варто усім вчитися користуватися доцільно технічними новаціями і можливостями IКТ.

У ході розроблення проблеми ми виявили, що питання організації дистанційної освітньої взаємодії за участю дітей старшого дошкільного віку мало представлені на ринку освітніх послуг. Хоча розробок наукових i методичних вдосталь. Однак, важливим моментом є вивчення специфіки такої освіти саме 3 дітьми старшого дошкільного віку. Зокрема, це: рівень самостійності дитини і можливість батьків супроводжувати i, за потребою, підтримати та допомогти дитині в користуванні медіа-трансляторами; часова відповідність нормам користування дитиною цифровими гаджетами; можливість 
організації за участю «рівний - рівному», коли дидактичні настанови дітьми від дітей старшого віку сприймаються швидше і точніше.

Важливими показниками готовності педагогічних працівників до реалізації дистанційної освіти для дітей старшого дошкільного віку уважаємо: розуміння педагогами і батьками дітей навколишнього середовища як відкритої інформаційної системи; системні знання про інформаційні процеси, сучасні інформаційні моделі та технології; здатність застосовувати програмні засоби загального призначення для отримання, обробки, збереження та передавання дидактичної інформації, використовувати інформаційно-комунікаційні і цифрові технології, спеціалізовані програмні продукти в освітній діяльності. Результати відповіді на питання про рівень загальної цифрової грамотності свідчать, що сума негативних відповідей склала 43,6\%, що трактується нами як проблема самоосвіти вільної і засобами вебінарів.

У ході анкетування ми намагалися виявити і компоненти педагогічного досвіду організації освітніх взаємодій із дітьми старшого дошкільного віку. Досвід використання цифрових технологій вказали 31,2\% опитаних, навички взаємодії з дітьми за допомогою цифрових технологій засвідчили 25,9\% опитаних, уміння конструктивно формувати цифровий контент, адаптувати його для дітей 5-6 років засвідчили лише 16,5\% опитаних. Це говорить про те, що більшість педагогічних працівників користуються готовими розробками усупереч авторським розробкам, де вони могли б втілити індивідуальний підхід і врахувати інтереси і запити реального контингенту вихованців.

Навички програмування засвідчили лише 5,8\% опитаних. Так само спостерігаємо низький відсоток позитивних відповідей на питання про уміння вирішувати технічні проблеми власних гаджетів (лише 19,7\%). Це означає, що без систематичної технічної підтримки педагогічні працівники не зможуть у прийдешній період реалізувати завдання дистанційної освіти у сфері дошкілля. Дещо вищі показники позитивних відповідей спостерігаємо на питання про можливості творчого використання цифрових і інформаційно-комунікаційних технологій $-31,7 \%$.

Уміння і навички із сфери цифрової безпеки засвідчили у відповідях лише $25,1 \%$ опитаних. Це серйозна проблема, яка потребує якнайшвидшого компенсуючого навчання широкого загалу педагогічних працівників.

У ході анкетування також виявлено проблему правдивості відповідей на запитання «Чи знаєте Ви як працювати з дітьми 5-6 років, щоб не нашкодити їхньому здоров'ю і психологічному комфорту?». Позитивних відповідей спостерігаємо 73,3\%, хоча обізнаність педагогічних працівників із питань цифрової безпеки майже втричі нижча $-24 \%$. Ймовірно, серед опитаних досить 
розмиті і формальні знання щодо безпечного використання ІКТ і цифрових гаджетів.

Другий етап дослідження передбачав вивчення контингенту батьків дітей старшого дошкільного віку, їхнє бачення дистанційних занять 3 дітьми. Проведене анкетування батьків дітей старшого дошкільного віку було спрямоване на визначення міри самостійності дітей, сформованості в дітей базових компетентностей, готовності батьків долучитися до підтримки дитини під час онлайн-занять, можливості забезпечити їх допомогою за потребою, необхідними для занять ресурсами. Зокрема, анкетування засвідчило про готовність і бажання батьків підтримати ідею проведення онлайн занять 3 дітьми. Позитивних відповідей 79\%, «не цікаво» - 12,4\%, «ні» - 8,6\%.

Рівень забезпечення необхідними ресурсами батьки так само продемонстрували досить високий - у середньому позитивні відповіді варіювалися у межах $81-84 \%$.

Також батькам було поставлене питання щодо виявлення міри самостійності дитини, сформованості у неї навичок, необхідних для розроблення серії онлайн-занять. Результати опитування представлені на рисунку 1 (Рис.1).

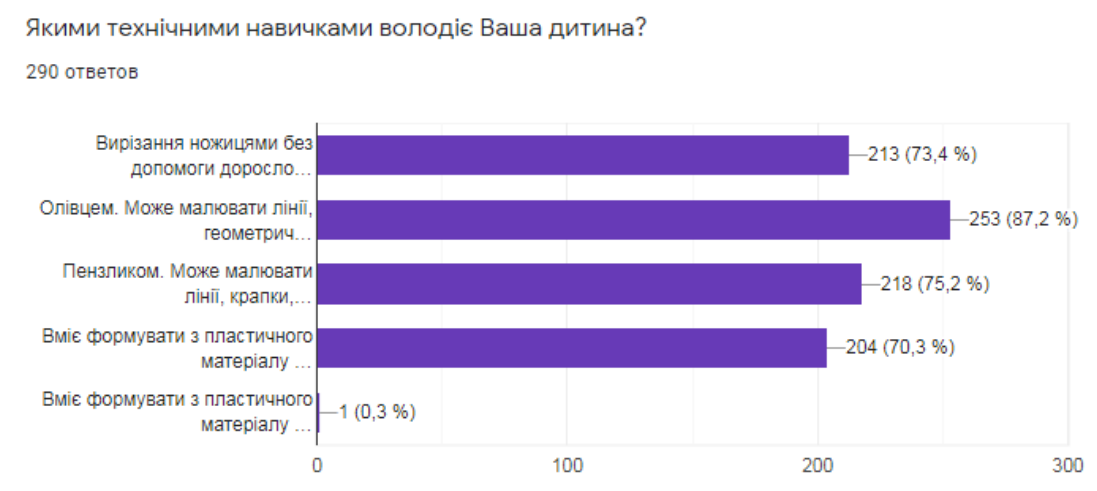

\section{Рис.1 Результати опитування батьків}

Учасники анкетування на добровільній основі отримали посилання на ресурси викладених у мережу Інтернет серії занять із дітьми старшого шкільного віку з використанням IКТ. Таким чином, було створено середовище активної педагогічної співпраці педагогічних працівників закладів дошкільної освіти, батьків дітей старшого дошкільного віку, організаторів дослідження. За бажанням, батьки дітей могли надіслати фото-звіти онлайн занять, власні відгуки про зміст і хід занять. Діти, які брали участь у проведенні онлайн-занять, отримали грамоти-відзнаки за участь у роботі. Розроблення і апробація змістовно-методичного контенту на прикладі серії онлайн занять 3 художньопродуктивної діяльності дітей старшого дошкільного віку було спрямоване на реалізацію авторського творчого підходу, змістовно заняття інтегрували 
художньо-продуктивну діяльність дітей старшого дошкільного віку і елементи математичної грамотності.

Перше онлайн-заняття було проведено на тему: «Виготовлення пляжного взуття дитиною для себе». Мета заняття: закріплювати навички вирізування та конструювання з паперу, розвиток фантазії і просторового мислення, освоєння понять геометричних фігур, розташування предметів у просторі, реалізацію природної потреби дитини у прикрашанні речей вжитку. Завдання перед організатором було таке: зацікавити дітей виконувати завдання самостійно, використовуючи відео-заняття (засобом залучення дитини шкільного віку для пояснення алгоритму виконання дій в ігровій формі), формувати самостійні навички роботи з ножицями, вирізування, обведення олівцем частин тіла (нога, рука), нанесення ліній для вирізування, використання клею. Матеріал: кольоровий папір, олівець, ножиці, клей ПВА або клей-олівець, декор для прикрашання виробу.

Алгоритм дій. Обираємо колір паперу для майбутнього взуття (пляжні капці). Обводимо олівцем ліву і праву стопу ноги. Вирізаємо. Олівцем наносимо на кольоровий папір лінії. Визначаємо ширину та довжину смужки - верхівки капців. Вирізаємо смужки. Використовуючи клей ПВА або клей-олівець, з'єднуємо смужки із вирізаною підошвою. Прикрашаємо взуття різноманітним декором. Приміряємо взуття, робимо фото на згадку.

Друге онлайн-заняття на тему: «Костюм індіанця». Мета: закріплювати навички вирізування та конструювання 3 паперу, робота олівцем під час виконання лінійного малюнка, елементів візерунка, розвиток уявлень про геометричні фігури, лічба у межах 10, реалізація потреби дитини в створення маскарадного костюма. Завдання: зацікавити дітей виконувати відео-заняття, стимулювати розвиток фантазії, закріпити поняття «горизонтальне і вертикальне положення аркушу паперу». Моделювання 3 паперу деталей одягу. Використовувати в одній роботі різноманітний матеріал: кольоровий та папіргофре, кольорові олівці. Матеріал: кольоровий папір і папір-гофре, олівець, ножиці, клей ПВА або клей-олівець, декор для прикрашання виробу.

Алгоритм diü. Обираємо колір паперу для майбутнього індіанського вбрання - роуч. Робимо основу для роучу (ободок) Визначаємо положення аркушу паперу - вертикально. Загинаємо папір. По лініях загину вирізаємо 2 смужки. Використовуючи клей, з'єднаємо дві лінії в одну довгу смужку. 3’єднаємо смужку в форму кола, використовуючи клей-олівець. Обов'язково необхідно приміряти окружність голови. Виготовляємо наступну деталь. Обираємо кольоровий папір. Положення аркуша паперу - горизонтальне. Загинаємо папір. По лінії згину вирізаємо. Отримуємо 2 симетричні прямокутні фігури. У роботі використовуємо 1 фігуру. Нанесемо на деталь візерунок у 
вигляді хвилястих і прямих ліній, горизонтальні чи вертикальні, крапки. Використовуємо кольорові олівці. 3’єднуємо деталі 1 і 2 за допомогою клею. Для прикрашання роучу використовуємо папір-гофре. Прикрашаємо роуч різноманітним декором. Приміряємо роуч. Фотографуємося. Граємо в індіанців.

Третє онлайн-заняття на тему: «Квіти для мами» передбачало малювання акварельними фарбами. Мета заняття: закріпити вміння зображати квіти, передати характерну форму вазону і квітів по пам'яті, формувати акуратність, уважність, розвивати зорову пам'ять. Завдання: зацікавити дітей виконувати завдання відео-заняття, спонукати їх творити подарунки для рідних людей, стимулювати розвиток фантазіі, уміння передати у малюнку розташування вази i квітів, визначити їх розмір. Матеріал: папір для малювання А4 формату, олівець, ластик, пензлики № 6, 2, акварельні фарби, серветки, 2 склянки з водою, палітра.

Алгоритм дій. Визначаємо положення аркуша паперу - вертикально. Визначаємо розмір букету квітів і вазону. Олівцем робимо розмітку на аркуші вазону і букету. Олівцем малюємо вазу у формі прямокутника. Нанесемо візерунок на вазу (вертикальні смужки). Олівцем малюємо квіти у формі кола. Обираємо колір вазону і смужок (тло вазону може бути білим, а смужки різнокольорові). Обираємо колір для квітів: червоний, жовтий. Акуратно будемо розфарбовувати малюнок. Подаруємо його мамі. Сфотографуємося разом із мамою і малюнком.

Тема наступного онлайн-заняття - «Рудий кіт». Малювання відбувається акварельними фарбами. Мета заняття: передати у малюнку будову фігури кота, форму частин тіла та їх відносну величину, розвивати у дітей фантазію, зорову пам'ять, виховувати акуратність. Завдання: зацікавити дітей виконувати завдання відео-заняття, визначити розмір і форму частин тіла тварини. Матеріал: папір для малювання А4 формату, олівець, ластик, пензлі № 6, 2, акварельні фарби, серветки, 2 склянки з водою, палітра.

Алгоритм дій. Визначаємо положення аркуша паперу - вертикально. Визначаємо розмір кота на аркуші. Олівцем робимо розмітку на аркуші: розмір голови і тулубу кота. Надаємо форму: голова у формі кола, тулуб - овальної форми. Олівцем малюємо котові очі, ніс, вуса, вуха. Обираємо колір для кота: жовтий або рудий (змішати фарби: червону і жовту). Акуратно розфарбувати малюнок. Можна підписати, давши котові кличку. Запропоновані онлайнзаняття мали такі особливості: тривалість 10-14 хвилин, мінімальні витрати на підготовку. Завдання і алгоритм їх виконання демонструвала дівчинка 11 років під керівництвом педагога. Завдання прості, орієнтовані на можливість дитини виконати їх без допомоги дорослих. Заняття не передбачали класичної структури, були позбавлені вимоги організації робочого місця. Акцент 
розробником було зроблено на зацікавленість дитини відео-заняттям i мінімізацією втручання з боку дорослих. Алгоритм дій простий, не потребував уточнень. Дозволялося використовувати альтернативні сучасні матеріали (пальчикові, їстівні фарби, замість пензлів, щіточки тощо) (Shtefan \& VorozhbitHorbatiuk, n. d.).

Реалізація запропонованих онлайн занять передбачає урахування оптимального навантаження на дитину з метою захисту від утоми, збереження іiі фізичного здоров'я; забезпечення емоційного благополуччя кожного учасника освітньої взаємодії; створення творчого розвивального середовища на грунті взаємодії з родиною щодо забезпечення повноцінного розвитку дітей (Nakaz Ministerstva okhorony zdorovia Ukrainy «Pro zatverdzhennia sanitarnoho rehlamentu dlia doshkilnykh navchalnykh zakladiv», 2016).

Обговорення. Отже, у ході дослідження було розроблено і здійснено анкетування педагогічних працівників закладів дошкільної освіти м. Харкова. Результати його засвідчили про зацікавленість педагогічних працівників ідеями дистанційної освіти дітей старшого дошкільного віку. Ідея безпечного розвивального середовища онлайн занять художньо-продуктивною діяльністю дітей старшого дошкільного віку полягали в тому, щоб інтегрувати знання в цілісне явище, максимально наближене до реального буття дитини (в онлайнзаняттях варто враховувати специфіку перебування дітей у сім'ї, логіку карантинних заходів тощо).

Онлайн заняття допомагають дитині створювати продукт, формувати культуру інформаційну, цифрову, загальну. Ситуаційний характер завдань дає право на множинність припустимих рішень. Особливо значимою для дитини старшого дошкільного віку $є$ можливість презентувати і зафіксувати своє досягнення. Зміст і рівень самостійної діяльності залежать від досвіду дітей у володінні конкретним видом діяльності, їхньої життєвої компетентності, наявності розвивального предметно-ігрового, природного, соціального середовища, врахування власного продуктивного простору кожної дитини. Це передбачає грамотне, дозоване керівництво з боку дорослого.

Висновки. Перспективним напрямом подальшого розроблення заявленої проблеми вбачаємо налагодження співпраці педагогів і батьків дітей в організації доцільних занять художньо-продуктивною діяльністю дітей онлайн, офлайн, за розробленими інструкціями чи простим алгоритмом дій. Наскрізним має стати завдання конкретики в осмисленні і розумінні позицій цифрової, комп’ютерної безпеки для фізичного і психічного здоров'я дитини старшого дошкільного віку. 
https://www.unicef.org/ukraine/iсторіi//вчимосявдома

Базовий компонент дошкільної освіти. Режим доступу: https://mon.gov.ua/ua/osvita/doshkilnaosvita/bazovij-komponent-doshkilnoyi-osviti-v-ukrayini

Ворожбіт-Горбатюк В. В., Штефан М.В. Художньо-продуктивна діяльність молодших підлітків: із досвіду інтегрованого курсу «Художня творчість». Науковий часопис НПУ імені М. П. Драгоманова, серія 5. 2021. Педагогічні науки, №79, т.1. С.77-81.

Ворожбіт-Горбатюк В. В., Попович О. М., Гербер С. М. Психолого-педагогічні умови підготовки майбутніх вихователів до організації конструктивної діяльності дошкільників. Міжнародний науковий журнал «Освіта $i$ наука». МукачевоЧенстохова: РВВ МДУ Академія ім. Я. Длугоша, 2018. С. 92-100.

Дичківська I. М. Інноваційні педагогічні технології [Текст]. Підручник. 2-е вид. допов. К.: «Академвидав», 2012. 352 с.

Дяченко С. В. Підготовка майбутніх вихователів до формування основ комп'ютерної грамотності старших дошкільників : дис. ... канд. пед. наук: спец. 13.00.04 Теорія і методика професійної освіти: Луган. нац. ун-т ім. Тараса Шевченка. Луганськ, 2009. $225 \mathrm{c}$.

Житнік Т. С. Розвиток художньо-творчої активності старших дошкільників засобами живопису. Автореферет дис. на здобуття наукового ступеня кандидата педагогічних наук за спеціальністю 13.00.08 - дошкільна педагогіка: Інститут проблем виховання НАПН України, К., 2015. 20 с.

Івершинь А. Г. Формування проектно-художніх уявлень у старших дошкільників. Автореферет дис. на здобуття наукового ступеня кандидата педагогічних наук за спеціальністю 13.00.08 - дошкільна педагогіка. К., 2001. 20 с.

Лист Міністерства освіти і науки України № 1/9-219 від 23.04.2020 «Щодо організації роботи закладів дошкільної освіти під час карантину». Режим доступу: https://mon.gov.ua/ua/npa/shodo-organizaciyi-roboti-zakladiv-doshkilnoyi-osviti-pid-chaskarantinu

Любченко Н. Формування інноваційного простору дошкільної освіти: наук.-метод. посіб. Ун -т менедж. освіти НАПН України. К., 2012. Ч. 1. 112 с.

Наказ Міністерства охорони здоров’я України «Про затвердження санітарного регламенту для дошкільних навчальних закладів» від 24.03.2016 № 234. Режим доступу: https://zakon.rada.gov.ua/laws/show/z0563-16

Штефан М. В., Ворожбіт-Горбатюк В. В. Серія онлайн занять для дітей старшого дошкільного віку художньо-продуктиавною діяльністю. Режим доступу: https://www.youtube.com/channel/UC6W7QXrSu63XiMa3 g7Zeiw?view_as=subscriber

\section{References:}

15 dniv \#VchymosiaVdoma [\#LearningAtHome] (n.d.). Retrieved from: https://www.unicef.org/ukraine/iсторіï/вчимосявдома (in Ukrainian).

Bazovyi komponent doshkilnoi osvity. [The basic component of preschool education] (n.d.). Retrieved from: https://mon.gov.ua/ua/osvita/doshkilna-osvita/bazovij-komponentdoshkilnoyi-osviti-v-ukrayini (in Ukrainian).

Vorozhbit-Horbatiuk, V. V. \& Shtefan, M. V. (2021) Khudozhno-produktyvna diialnist molodshykh pidlitkiv: iz dosvidu intehrovanoho kursu «Khudozhnia tvorchist». [Artistic and productive activity of younger teenagers: from the experience of the integrated course "Artistic creativity"]. Naukovyi chasopys NPU imeni M. P. Drahomanova, seriia 5. Pedahohichni nauky, №79, t.1. S.77-81 (in Ukrainian).

Vorozhbit-Horbatiuk, V. V., Popovych, O. M. \& Herber, S. M. (2018). Psykholoho-pedahohichni umovy pidhotovky maibutnikh vykhovateliv do orhanizatsii konstruktyvnoi diialnosti doshkilnykiv. [Psychological and pedagogical conditions of preparation of future educators for the organization of constructive activity of preschoolers]. Mizhnarodnyi naukovyi zhurnal 
«Osvita i nauka». Mukachevo-Chenstokhova: RVV MDU Akademiia im. Ya. Dluhosha, S. 92-100 (in Ukrainian).

Dychkivska, I. M. (2012). Innovatsiini pedahohichni tekhnolohii. [Innovative pedagogical technologies]. Pidruchnyk. 2-e vyd. dopov. K.: «Akademvydav». 352 s. (in Ukrainian).

Diachenko, S. V. (2009). Pidhotovka maibutnikh vykhovateliv do formuvannia osnov kompiuternoi hramotnosti starshykh doshkilnykiv. [Preparing future educators to form the basics of computer literacy of senior preschoolers]: dys. ... kand. ped. nauk: spets. 13.00.04 Teoriia i metodyka profesiinoi osvity: Luhan. nats. un-t im. Tarasa Shevchenka. Luhansk. 225 s. (in Ukrainian).

Zhytnik, T. S. (2015). Rozvytok khudozhno-tvorchoi aktyvnosti starshykh doshkilnykiv zasobamy zhyvopysu. [Development of artistic and creative activity of senior preschoolers by means of painting]. Avtoreferet dys. na zdobuttia naukovoho stupenia kandydata pedahohichnykh nauk za spetsialnistiu 13.00.08 - doshkilna pedahohika: Instytut problem vykhovannia NAPN Ukrainy, K., 20 s. (in Ukrainian).

Ivershyn, A. H. (2001). Formuvannia proektno-khudozhnikh uiavlen u starshykh doshkilnykiv. [Formation of design and artistic ideas in older preschoolers]. Avtoreferet dys. na zdobuttia naukovoho stupenia kandydata pedahohichnykh nauk za spetsialnistiu 13.00.08 - doshkilna pedahohika. K., 20 s. (in Ukrainian).

Lyst Ministerstva osvity i nauky Ukrainy № 1/9-219 vid 23.04.2020 «Shchodo orhanizatsii roboty zakladiv doshkilnoi osvity pid chas karantynu». [Letter of the Ministry of Education and Science of Ukraine № 1 / 9-219 dated 23.04.2020 "Regarding the organization of the work of preschool education institutions during quarantine"]. (2020) Retrieved from: https://mon.gov.ua/ua/npa/shodo-organizaciyi-roboti-zakladiv-doshkilnoyi-osviti-pid-chaskarantinu (in Ukrainian).

Liubchenko, N. (2012). Formuvannia innovatsiinoho prostoru doshkilnoi osvity. [Formation of innovative space of preschool education]: nauk.-metod. posib. Un -t menedzh. osvity NAPN Ukrainy. K., Ch. 1. 112 s. (in Ukrainian).

Nakaz Ministerstva okhorony zdorovia Ukrainy «Pro zatverdzhennia sanitarnoho rehlamentu dlia doshkilnykh navchalnykh zakladiv» vid 24.03.2016 № 234. (2016). [Order of the Ministry of Health of Ukraine "On approval of sanitary regulations for preschool educational institutions" from 24.03.2016 № 234]. Retrieved from: https://zakon.rada.gov.ua/laws/show/z0563-16 (in Ukrainian).

Shtefan, M. V. \& Vorozhbit-Horbatiuk, V. V. (n. d.) Seriia onlain zaniat dlia ditei starshoho doshkilnoho viku khudozhno-produktyavnoiu diialnistiu. [A series of online classes for older preschool children with artistic and productive activities]. Retrieved from: https://www.youtube.com/channel/UC6W7QXrSu63XiMa3_g7Zeiw?view_as=subscriber (in Ukrainian).

\section{Інформація про автора: \\ Штефан Марина Владиславівна, ORCID: $\quad$ https://0000-0002-0304-1567,} здобувач третього (освітньо-наукового) рівня вищої освіти кафедри освітології та інноваційної педагогіки, Харківського національного педагогічного університету імені Г.С. Сковороди, вул. Валентинівська, 2, м. Харків, Україна 61000,

e-mail: shtefan.maris@gmail.com

\section{Information about the author:}

\section{Shtefan Maryna Vladyslavivna,}

ORCID: https://0000-0002-0304-1567, PhD candidate of the Department of Education and Innovative Pedagogy of H. S. Skovoroda Kharkiv National Pedagogical University, Valentynivska, street, 2, Kharkiv, Ukraine, 61000 ,

e-mail: shtefan.maris@gmail.com 
Цитуйте цю статтю як: Штефан М. В. Створення безпечного розвивального середовища онлайн занять художньо-продуктивною діяльністю старших дошкільників. Теорія та методика навчання та виховання. 2021. № 51. С. 173-184. DOI: $10.34142 / 23128046.2021 .51 .16$

Дата надходження статті до редакції: 7.10.2021

Стаття прийнята до друку: 22.10.2021 